\section{К разработке стратегии развития регионального лесного комплекса}

\author{
И. Р. Шегельман ${ }^{1}$ \\ Петрозаводский государственный университет
}

\begin{abstract}
АННОТАЦИЯ
Рассматриваются состояние и проблемы лесного комплекса Республики Карелия. Сформулированы методические предпосылки к разработке стратегии развития комплекса.
\end{abstract}

Ключевые слова: лесной комплекс, система управления, стратегия развития.

\section{SUMMARY}

The status and problems of the forest complex in the Republic of Karelia are considered in the article. Some methodical preconditions for the development of the forest complex evolution strategy are formulated.

Keywords: a wood complex, system managements, strategy of development.

Ситуация в лесном комплексе, являющемся основой экономики Республики Карелия, сложнейшая. Ухудшается финансовое состояние лесопромышленных предприятий, недоперечисляются средства в бюджеты всех уровней, что негативно сказывается на финансовом и социальном состоянии районов и поселков Карелии. Выход из кризиса и развитие лесного комплекса необходимы для формирования бюджетов Карелии и Федерации, создания новых производств, вовлечения в промышленную сферу и инфраструктуру кадров различного уровня, выхода на зарубежный рынок и привлечения инвестиций в условиях присоединения к ВТО.

В числе острых проблем управления лесным фондом Карелии - несовершенство лесного законодательства, слабо развитая сеть лесных дорог, необходимость увязать экономические, социальные и экологические задачи.

Задача органов управления лесами - обеспечить экологически безопасное освоение и последующее восстановление лесных ресурсов, задача лесопользователей - заготовить древесину с минимальными затратами. Задача государства - сбалансировать интересы различных ведомств, лесопромышленных структур и населения и обеспечить развитие экономики республики, неистощительное многоцелевое использование и воспроизводство лесов.

Масштаб проблем, стоящих перед отраслью, таков, что предприятия не в состоянии решить их собствен-

\footnotetext{
${ }^{1}$ Автор - профессор, зав. кафедрой технологии и оборудования лесного комплекса, депутат 3С РК ○ И. Р. Шегельман, 2003
}

ными силами. Важнейшая задача - привлечение инвестиций. Аналитики ведущих инвестиционных компаний считают необходимым привлечь в лесной комплекс не менее 5 млрд дол. США в год, к чему российские участники рынка явно не готовы. В 2001 г. предприятия отрасли инвестировали около 14 млрд руб., что близко к пределу их возможностей. Лишь государство может создать предпосылки для стабильного притока капиталов в отрасль, ликвидировав препятствия на пути инвестора [2].

В России осваивается около $23 \%$ расчетной лесосеки, составлявшей в 2000 г. в лесах ведения Министерства природных ресурсов России 513 млн. м ${ }^{3}$ [2]. Существует дисбаланс между запасами древесины и размерами лесопользования в Европейско-Уральском регионе, где запас спелых лесов не выше $18 \%$ от общероссийского, а заготавливается более 57 \% древесины [1]. Расчетная лесосека по хвойному хозяйству в России в 2000 г. была использована на $28,8 \%$, в Северном регионе - на 45,8, Северо-Западном - 66, Центральном - 76,4, Волго-Вятском - на 71,9 \%.

Наличие в европейской части страны развитой инфраструктуры, значительных мощностей по переработке, разветвленной сети дорог, близость к экспортным рынкам сбыта, устойчивый внутренний спрос на лесную продукцию способствуют дальнейшему наращиванию объемов лесозаготовок в этих районах. М. Д. Гиряев ставит справедливый вопрос - каковы же резервы роста объема лесозаготовок в этих районах? [3]. Такая постановка вопроса закономерна, так как расчетная лесосека по рубкам главного пользования устанавливается без учета транспортной доступности спелых древостоев и рентабельности их заготовки.

За последние 32 года резко снизилась доля спелых и перестойных хвойных древостоев, увеличилась хвойных молодняков и средневозрастных насаждений. В Карелии соответственно с 61 до 33 и с 31 до 60 [1]. Низок удельный вес приспевающих древостоев, значительны площади лесных культур.

В эксплуатационных лесах Карелии преобладают перестойные древостои, средний запас на 1 га спелых и перестойных древостоев значительно ниже, чем приспевающих. В лесном фонде Карелии запас на 1 га перестойных древостоев меньше запаса спелых на $13 \mathrm{~m}^{3}$, приспевающих - на 56 м $^{3}$ и практически равен запасу на 1 га средневозрастных насаждений. Запас на 1 га приспевающих насаждений был выше спелых в 2000 г. на $31 \mathrm{~m}^{3}$. В переданном лесозаготовителям лесосечном фонде в 2000 г. преобладала средняя деловая древесина хвойных пород (14-24 см). Значительна доля мелкой древесины (6-13 см). Наличие значительного количества мелкотоварной древесины в лесосечном фонде снижает рентабельность и не способствует экономической стабилизации лесозаготовительных предприятий.

Протяженность лесовозных дорог в лесном фонде до 1993 г. неуклонно возрастала, с 1993 по 1998 г. в свя- 
зи с прекращением строительства снизилась в России на 30 тыс. км, в Европейско-Уральской зоне - на 54 тыс. км [3].

По мнению М. Д. Гиряева [3] и ряда других специалистов, в связи со значительным наличием нерентабельных, деконцентрированных перестойных и спелых древостоев, прекращением строительства лесных дорог, а также последствиями кризиса в большинстве регионов расчетная лесосека по главному пользованию в хвойном хозяйстве транспортно доступных лесов и в рентабельных древостоях практически осваивается на $100 \%$. В связи с изложенным представляется обоснованным позиция Росгипролесхоза по созданию целевых хозяйств.

Проблемы управления лесным фондом Карелии близки к проблемам смежных лесопромышленных регионов Северо-Западного федерального округа. В их числе, как подтвердил целый ряд обсуждений со специалистами Республики Коми, Вологодской, Ленинградской, Мурманской и др. областей, несовершенство законодательства, скудное финансирование лесовосстановительных работ, слабо развитая сеть лесных дорог, а также ненайденный (в отличие от стран Запада) разумный компромисс между специалистами лесного хозяйства и лесозаготовок и др.

Устойчивое управление лесами имеет много особенностей по сравнению с другими отраслями, основные из них характеризуются следующим [5]:

- длительный циикл, завершающийся выращиванием спелого леса;

- многочелевое использование лесных ресурсов, включающее заготовку древесины по главному и промежуточному пользованию, заготовку недревесных продуктов, использование средообразующих, санитарно-гигиенических и др. функций лесов;

- зависимость от природных, климатических, техногенных и др. факторов;

- высокий экономический риск в принятии управленческих решений из-за чрезмерной продолжительности технологического иикла получения готовой продукиии - спелой древесины;

- влияние региональных условий использования и воспроизводства лесных ресурсов (транспорт, рынки сбыта, переработки и др.).

Резерв повышения доходности лесов в настоящее время заложен в рыночных формах пользования участками лесного фонда путем аренды, продажи древесины на корню на лесных аукционах. В Карелии уже в 2000 г. передано в аренду 6,2 млн га лесных земель с объемом лесопользования по главному пользованию 4386 тыс. м ${ }^{3}$ в год. Заключено 108 договоров аренды. В 2001 г. продано на лесных аукционах 205,8 тыс. м ${ }^{3}$ древесины, цена продаж одного обезличенного кубометра составила 154 руб. [5].
Важнейшими рычагами экономического механизма являются платежи за пользование лесными ресурсами. Специалисты выделяют два подхода к формированию попенной платы, или налога за пользование древесиной на корню, как главного регулятора лесопользования [4]: затратный - в странах с централизованной экономикой; рыночный - в странах с рыночной экономикой, где величина попенной платы формируется в зависимости от уровня цен на круглые лесоматериалы. Государство должно следить за тем, чтобы доходы от лесопользования не перекачивались в сферу частного предпринимательства, а принадлежали всему обществу и использовались в первую очередь на охрану и воспроизводство лесов.

Из-за продолжающегося выделения особо охраняемых природных территорий (ООПТ) площадь лесов в республике, где ранее была возможна их эксплуатация, сокращается. К природно-заповедному фонду отнесен почти 1 млн га лесных земель, а с учетом перспектив проектирования национальных (природных) парков к 2005 г. и с учетом лесов первой группы (водоохранных, нерестоохранных и др.) этот показатель может увеличиться до 2,6 млн га.

В Карелии традиционно высокий по сравнению с другими регионами уровень освоения расчетной лесосеки. Расчетная лесосека по УПР РК в 2002 г. составила 9209,7 тыс. м³. На 01.01.2003 г. фактически было отпущено древесины на корню лесопользователям $6697 \mathrm{~m}^{3}$ (использование расчетной лесосеки по отпуску $73 \%$ ), фактически заготовлено 6118, 5 м $^{3}$ (использование расчетной лесосеки по заготовке $66 \%)$.

Наиболее высокой уровень освоения расчетной лесосеки в 2002 г. в Лахденпохском районе (Лахденпохский лесхоз) - $100 \%$, в Пряжинском (Пряжинский и Шуйско-Виданский лесхозы) - $92 \%$, в Муезерском (Муезерский и Суккозерский лесхозы) - 87 \%, в Суоярвском (Поросозерский и Суоярвский лесхозы) - 87 $\%$, в Питкярантском районе (Питкярантский лесхоз) 84 \% и в Сортавале (Сортавальский лесхоз) - $84 \%$. Наиболее низкий уровень освоения расчетной лесосеки в Лоухском районе (Пяозерский и Чупинский лесхозы) - 39 \%, в Костомукше (Костомукшский лесхоз) - $44 \%$, в Кемском (Кемский лесхоз) - $50 \%$, в Калевальском (Калевальский и Юшкозерский лесхозы) - 55 \% и в Пудожском районах (Пудожский и Пяльмский лесхозы) $-56 \%$.

В 2002 г. заготовлено рубками ухода 80,3 тыс. м², прочими рубками $-42,2$ тыс. м³. Местными администрациями вырублено: в рамках бюджетной сферы 236,3 тыс. м $^{3}$ (отпущено - 293,0 тыс. м ${ }^{3}$ ), местным населением - 93,3 тыс. м ${ }^{3}$ (отпущено - 106, 1 тыс. м $^{3}$ ). Предприятиями Минсельхозпрода РК заготовлено 172, 5 тыс. м ${ }^{3}$ (отпущено - 197,7 тыс. м³). При выполнении инвестиционной программы 2002 г. УКСом Госстроя РК заготовлено 173,5 тыс. м³ (отпущено 212,8 тыс. м ${ }^{3}$ переходит на 2003 г. $-4,3$ тыс. м³). 
В последние годы общественные движения требуют основательного пересмотра политики в области ведения лесного хозяйства и оказания большего внимания защите окружающей среды. По-прежнему серьезными проблемами в лесном комплексе остаются нарушения лесохозяйственных требований и правил пожарной безопасности, рост числа самовольных рубок, интенсификация лесопользования в лесах, исключенных из расчета главного пользования.

Имеются серьезнейшие проблемы с переводом лесных земель в нелесные при строительстве карьеров для лесовозных дорог. Принятие решений о предоставлении земельных участков превышает все допустимые пределы. В июле с. г. в Минприроде РФ находилось 60 землеустроительных дел из Карелии, некоторые с 1998 г. Сроки оформления земель под карьеры в Запкареллесе - 1 год 3 месяца, в лесничествах Поросозерского лесхоза - 2 года, Пяозерском ЛПХ - 10 месяцев. Получается абсурд. Лесозаготовители, строя дороги, фактически развивают инфраструктуру лесных поселков и повышают экономическую доступность лесов. Поэтому признание разработки песчано-гравийных карьеров для строительства лесных дорог действием, связанным с ведением лесного хозяйства и пользованием лесным фондом, необходимо для жизнеобеспечения субъектов Федерации с развитой лесной промышленностью.

Изложив перечисленные проблемы, нельзя не коснуться проблем, неоднократно поднимаемых карельскими лесозаготовителями:

- низкая экономическая доступность лесного фонда (декониентрачия, низкий запас на га, низкий выход деловой древесины, сложные природнопроизводственнье условия, низкий уровень «летнего» лесфонда и т. п.),

- износ основных фондов подошел к критической точке;

- республика все еще не приступила к серьезной работе по сертификации лесных ресурсов;

- объем расчетной лесосеки имеет тенденцию к снижению и находится под необоснованно пристальным вниманием «Гринпис»;

- значительная часть лесного фонда - перестойные насаждения, поврежденные стволовыми гнилями и имеющие низкую товарность, выход деловой древесины с ряда лесосек по хвойным породам не более $60 \%$, по лиственным - значительно ниже;

- в лесозаготовительной отрасли низкий уровень заработной платы;

- все еще велик удельный вес насаждений, вышедших из подсочки (Муезерский район);

- не разрешена ситуация с низкосортной древесиной и древесиной осины и др.

Для решения сформулированных проблем необходимо ускорить совершенствование системы управления лесопромышленным комплексом Республики Каре- лия, разработать и реализовать государственную региональную стратегию лесопользования, решить проблему обоснованной передачи лесного фонда в аренду. Управление лесными ресурсами должно базироваться на государственной стратегии, увязанной с решением триединой задачи: экономической, социальной и экологической. Основными критериями эффективности в данном подходе являются рациональность, комплексность использования ресурсов и бюджетная эффективность.

Необходима государственная лесная политика, основанная на следующих принципах:

- государство несет ответственность за проведение экономических реформ и обязано регулировать их проведение, исключив возможность возникновения региональных рисков и социальных взрывов;

- государство должно эффективно использовать механизмы управления лесными ресурсами, работать с предприятиями через контрольные пакеть акций, обеспечить согласительную политику крупных предприятий подотраслей ЛПК, разрабатьвать программы развития подотраслей, оптимизируя лесопромышленные структуры и их размещчение,

- стратегия должна основываться на рациональной схеме управления лесными ресурсами и базироваться на научно обоснованном региональном балансе производства и потребления лесоматериалов.

Государство как собственник лесов, пользующийся правом получения лесной ренты, обязано обеспечить:

- устойчивое управление лесами, рациональное лесопользование и воспроизводство лесных ресурсов;

- нормальное функиионирование механизма рыночных отношений с учетом баланса интересов всех участников рынка, не допуская монопольного владения лесами;

- оптимизачию сочетания площадей, передаваемых как в долгосрочную, так и в краткосрочную аренду;

- создание условий для безболезненного перетекания потоков древесного сырья с внешнего рынка на внутренний путем углубления переработки древесины в регионе (как химической, так и механической),

- необходимые условия для гарантированного финансирования расходов на охрану и воспроизводство лесных ресурсов;

- инвестиционную привлекательность лесных ресурсов, в т. ч. и за счет долговременной аренды,

- научно обоснованный региональный баланс производства и потребления лесоматериалов;

- предотвращение необратимых изменений климата и лесной среды и др.

Принципы передачи участков леса в аренду должны определяться: 
- установленными законодательством правами собственности на землю и выделяемые в аренду участки лесного фонда региона;

- формами передачи участков лесного фонда лесопользователям (собственность, управление, краткосрочная и долгосрочная аренда, концессия);

- государственной стратегией в области комплексности использования древесины;

- установленным периодом передачи участков леса в пользование;

- характеристиками лесопользователей и эффектом, который получит государство (общество) от передачи им лесного фонда.

Государственное управление должно осуществляться на основе обоснованных всеми претендентами на аренду коммерческих проектов, программ, бизнеспланов, масштабность и глубина действий которых будет достигнута не за счет «гигантизма» проектов, а за счет системного воздействия на весь комплекс социально-экономических и культурно-политических процессов. В данные проекты необходимо включать мероприятия по развитию критических районов лесопромышленного комплекса Республики Карелия.

\section{ЗАКЛЮЧЕНИЕ}

В управлении лесным комплексом Карелии накоплены серьезные проблемы, вызванные несовершенством действующего законодательства, скудным финансированием лесовосстановительных работ, задолженностями перед лесозаготовителями за выполнение этих работ, слабо развитой сетью лесных (лесовозных, лесохозяйственных) дорог, отсутствием средств на их строительство и эксплуатацию и др.

Изменить ситуацию можно, приняв и реализовав стратегию региональной лесопромышленной политики, исключающую возникновение региональных рисков и социальных взрывов. Стратегия должна предусматривать рациональную схему управления лесными ресурсами и базироваться на обоснованном региональном балансе производства и потребления лесоматериалов в регионе. Основной метод государственного управления на данном этапе развития рыночных отношений в ЛПК - управление лесными ресурсами. ния взаимосвязанных действий, обеспечивающих повышение эффективности управления лесами и лесопользования в Республике Карелия, основными критериями которой являются рациональность, комплексность использования ресурсов и бюджетная эффективность.

\section{СПИСОК ЛИТЕРАТУРЫ}

1. Белаенко А. П. Лесопользование в условиях реформы управления природными ресурсами // Лесное хозяйство. 2002. № 3. С. 9-11.

2. Беляков А. С. Проблемы развития и законодательного обеспечения лесного комплекса // Лесопромышленный комплекс России XXI века: Тез. докл. межд. форума. М., 2002. С. 70-71.

3. Гиряев М. Д. Лесоводственные и экономические аспекты организации лесопользования // Лесное хозяйство. 2002. № 2. С. 2-5.

4. Селицкая Е. Н., Мещерякова Е. В. Ценовая политика на лесные ресурсы в условиях рынка // Лесная промышленность. 1999. № 5. С. 29-32.

5. Скадорва И. В. Проблемы управления лесами в Республике Карелия // Современные проблемы развития лесопромышленных производств: Научные труды. № 6 / КРИА. Петрозаводск, 2001. С. 3-5. (Сер. Лесопромышленный комплекс).
Изложенные проблемы и рекомендации могут быть использованы при разработке стратегии осуществле- 